\title{
SUBSTITUENT EFFECTS ON THE ABSORPTION AND VIBRATIONAL SPECTRA OF SOME 2-HYDROXY SCHIFF BASES: DFT/TDDFT, NATURAL BOND ORBITAL AND EXPERIMENTAL STUDY
}

\author{
S.A. Elroby ${ }^{1,3}$, S. Aboud ${ }^{1}$, S.G. Aziz ${ }^{1}$, R. Hilal ${ }^{1,2}$ \\ ${ }^{1}$ Chemistry Department, Faculty of Science, King abdullaziz University, Jeddah, Saudi Arabia \\ E-mail: rhilal@kau.edu.sa \\ ${ }^{2}$ Chemistry Department, Faculty of Science, Cairo University, Giza, Egypt \\ ${ }^{3}$ Chemistry Department, Faculty of Science, Benisuef University, Benisuef, Egypt
}

Received March, 5, 2014

\begin{abstract}
The electronic structure of salicylideneaniline (SA) and some of its derivatives are investigated both experimentally and theoretically. The equilibrium geometric structures of the studied compounds are determined at the B3LYP/6-311++G** level of theory. A set of 12 substituted SA derivatives is considered in the present work. The choice of these substituents aims to create a push-pull system on the SA basic structure which would shade light onto its photo physics. The electronic absorption spectra of SA are recorded in the UV-VIS region, in both polar and nonpolar solvents. Assignments of the observed electronic transitions are facilitated via timedependent density functional theory (TDDFT) computations at the same level of theory. Electronic configurations contributing to each excited state are identified and the relevant MOs are characterized. The extent of delocalization and intramolecular charge transfer are estimated and discussed in terms of natural bond orbitals (NBO) analysis and second order perturbation interactions between donor and acceptor MOs. Solvent effects on the electronic absorption spectra are discussed in terms of the difference in polarizabilities of the ground and excited states. FTIR spectra of SA and its derivatives are measured in $\mathrm{KBr}$ platelets. Detailed vibrational assignments are given based on the calculated potential energy distributions. "IR marker bands" that characterize the SA framework are identified. The effect of substituents, the nature of the characteristic "marker bands", and intensity quenching of some bands are discussed.
\end{abstract}

DOI: $10.15372 / \mathrm{JSC} 20150303$

Ke y w o r d s: electronic spectra, vibrational spectra, DFT/TDDFT, solvent and substituent effects, NBO analysis, 2-hydroxy Schiff bases.

\section{INTRODUCTION}

Aromatic Schiff bases have been [ $1-4$ ] and still are the subject of numerous studies because of possible applications, e.g. in molecular memories and switches [5-7]. This class of molecular systems is of fundamental interest because it shows two interesting phenomena, namely, the excited state intramolecular proton transfer (ESIPT) and photochromism. The best known photochromic Schiff base is salicylideneaniline (SA). This molecule and its derivatives have been widely studied over a wide span of time [ 8-24]. In SA and its derivatives, the intramolecular hydrogen bonding opens a possibility of fast proton transfer between different tautomers followed by isomerization changes, leading to a metastable photochromic modification of the initial structure. Numerous experimental studies [2528 ] on SA have been devoted to the analysis of the mechanism and dynamics of the proton transfer

(C) Elroby S.A., Aboud S., Aziz S.G., Hilal R., 2015 
reaction from the primary excited enol form to the keto tautomer and the creation of the photochromic tautomer in the ground electronic state. Nevertheless, the results are not fully consistent and much controversy is still present.

The absorption spectrum of SA shows a quite prominent band at $300-400 \mathrm{~nm}$ attributed to the photoexcitation to a $\pi \pi^{*}$ excited state [29]. The fluorescence spectrum also presents a single largely Stokes shifted band centered at around $570 \mathrm{~nm}$. This band is believed to come from the cis-keto tautomer and is also a $\pi \pi^{*}$ state. The quantum yield of the fluorescence is quite low [24]. A global picture of photochromism in SA has been reached based on the time- resolved experiments [24,29]. This picture starts with photoexcitation to the $\pi \pi^{*}$ excited state followed by a quick transfer of the hydroxylic proton to the nitrogen imino atom resulting in the fluorescent cis-keto tautomer. This species is the precursor of the photochromic transient, believed to be a ground state keto tautomer. This transient has a long lifetime of the order of milliseconds and a maximum absorption band at $474 \mathrm{~nm}$ [24 ]. However, the detailed mechanism about the species involved in the whole process and the time of the different steps is not a settled question. In fact, several different decay mechanisms have been proposed, namely, thermal deactivation and internal conversion (IC) through conical intersections (CIs) or intersystem crossing.

The present work attempts to provide a detailed experimental and quantum chemical study of the electronic and vibrational spectra of SA at high level DFT and TDDFT methods. The origin of each absorption band is identified and the contributing configurations and MOs are characterized. The magnitude and direction of the intramolecular charge transfer is also identified and evaluated. In this respect, natural bond orbital analysis (NBO) is carried out to identify the extent of delocalization and the charge transfer of the electron density in the studied molecular systems. The effect of substituents on the vibrational spectra is also investigated. An attempt is made to identify and assign the "IR marker bands" for SA. Solvent and substituent effects are quantitatively analyzed and discussed.

\section{EXPERIMENTAL}

Compounds. SA and its derivatives were prepared by conventional methods where equimolar quantities of aniline and salicylaldehyde were heated in spectroscopically pure dry ethanol and then the solution was allowed to cool. Compounds were then recrystallized from chloroform.

Solvents. Spectroscopic-grade solvents (Merck) were used without any further purification.

Measurements. Infrared spectra of the compounds were recorded on a Shimad24 820/PC FT-IR spectrometer within the range $4000-400 \mathrm{~cm}^{-1}$. For samples in the solid state, the IR spectra were measured in $\mathrm{KBr}$ pellets at a resolution of $1 \mathrm{~cm}^{-1}$. All UV-VIS spectral measurements were carried out using a Perkin-Elmer UV-Visible spectrophotometer (model Lambda 2).

Computational methods. All computations were carried out using the Gaussian 09W software package [30 ]. Molecular geometries of all of the studied compounds were fully optimized using the $6-311++\mathrm{G}^{* *}$ basis set using Beck's three-parameter-hybrid (B3LYP) DFT method [31-33 ]. No symmetry constrains were applied during the geometry optimization. Calculations of the electronic spectra and excited states were carried out at the TDDFT/6-311++G** level of theory [34]. The choice of this basis set was due to its flexibility, and the fact that diffuse $p$ functions on the hydrogen atoms tend to compensate the anharmonic effects of the $\mathrm{CH}$ and $\mathrm{NH}$ stretches. The force constants were analytically computed at the fully optimized geometries. NBO calculations have been performed at the B3LYP/6-311+G** level using the NBO 3.1 program as implemented in the Gaussian09W software package in order to quantitatively measure the intramolecular delocalization in the studied systems. NBO theory [35,36] proved to be extremely useful in analyzing hyper conjugative [37] interactions through the second-order perturbation energy $\left(E^{(2)}\right)$, which is estimated as

$$
E^{(2)}=\Delta E_{i j}=q_{i}\left(F_{i j}\right)^{2} / \Delta \varepsilon,
$$

where $q_{i}$ is the donor orbital occupancy, $\Delta \varepsilon$ is the difference between the energy of an acceptor orbital $(j)$ and a donor orbital $(i)$, and $F_{i j}$ is the off-diagonal NBO Kohn-Sham matrix. Throughout this work MOs were constructed using the Gauss View 5.0.8 visualization program [38 ]. 

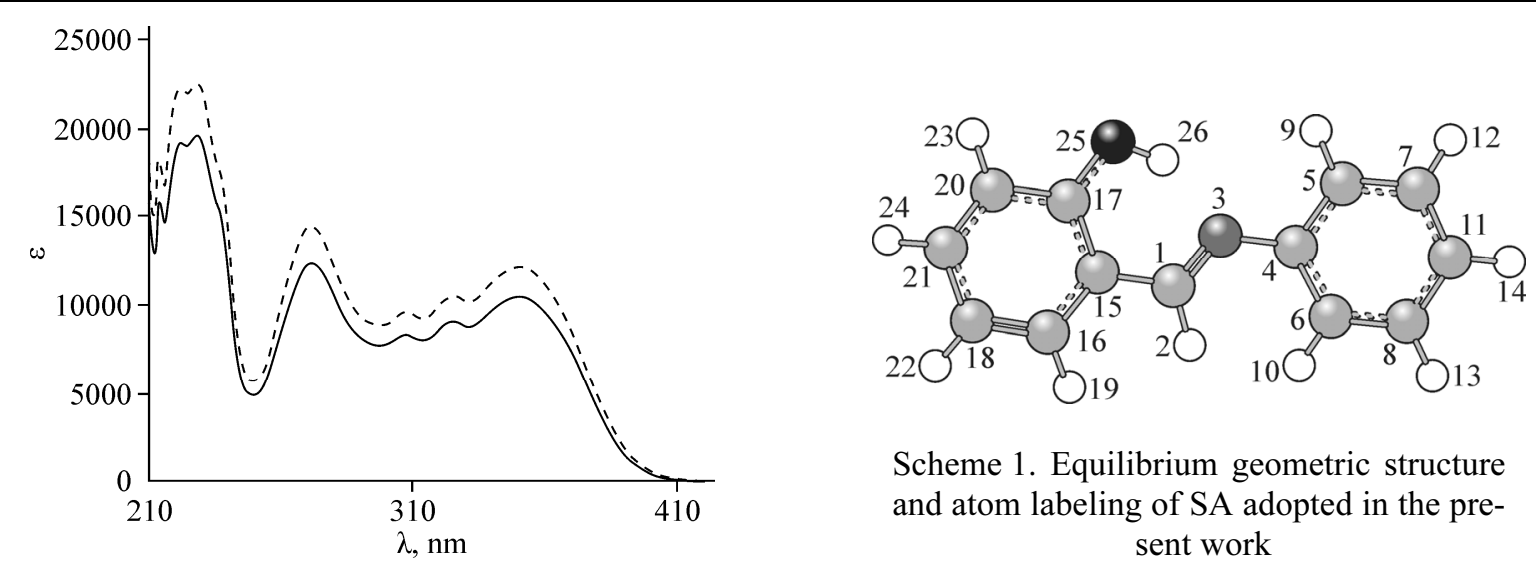

Scheme 1. Equilibrium geometric structure and atom labeling of SA adopted in the present work

Fig. 1. Electronic absorption spectra of SA, in (-) cyclohexane and (---) ethanol as solvents

\section{RESULTS AND DISCUSSION}

Electronic and vibrational spectra of SA. Scheme 1 displays the equilibrium geometric structure and the numbering system of SA adopted in the present work.

Fig. 1 displays the electronic absorption spectrum of SA in cyclohexane and ethanol as solvents. The spectrum is composed of low intensity diffuse bands. One can identify five overlapping bands and a shoulder, spanning the $350-200 \mathrm{~nm}$ range. An increase in the solvent polarity causes a marked blue shift of all observed transition bands. Table 1 presents the electronic spectral characteristics of SA in both polar and nonpolar solvents. It is instructive at this point to identify the origin of these observed transition bands. A comparison between the observed and theoretically computed spectra is given in Table 1. The correspondence is excellent. The first transition which is predicted at $353 \mathrm{~nm}$ (observed $350 \mathrm{~nm})$ is composed of two main configurations: $51 \rightarrow 53(-0.18)$ and $52 \rightarrow 53(0.68)$. MOs involved

T a b l e 1

Experimentally observed and theoretically predicted spectral characteristics of SA

\begin{tabular}{|c|c|c|c|c|c|c|c|c|c|}
\hline \multicolumn{2}{|c|}{ Observed $\lambda, \mathrm{nm}$} & \multicolumn{4}{|c|}{ Theoretically predicted for SA enol } & \multicolumn{4}{|c|}{ Theoretically predicted for SA cis-keto } \\
\hline Cyclohexane & Methanol & $E, \mathrm{eV}$ & $\lambda, \mathrm{nm}$ & $f$ & Contribution & $E, \mathrm{eV}$ & $\lambda, \mathrm{nm}$ & $f$ & Contribution \\
\hline \multirow{4}{*}{353} & \multirow{4}{*}{345} & \multirow{5}{*}{3.51} & \multirow{5}{*}{353} & \multirow{5}{*}{0.4} & \multirow{5}{*}{$\begin{array}{l}51-53(0.18) \\
52-53(0.68)\end{array}$} & 2.96 & 419 & 0.3 & $52-53(0.77)$ \\
\hline & & & & & & 3.21 & 386 & 0.0 & $51-53(0.70)$ \\
\hline & & & & & & & & & \\
\hline & & & & & & & & & \\
\hline 322 & 327 & & & & & 3.91 & 317 & 0.4 & $50-53(0.70)$ \\
\hline \multirow[t]{3}{*}{305} & \multirow[t]{3}{*}{300} & \multirow[t]{2}{*}{4.07} & \multirow[t]{2}{*}{305} & \multirow[t]{2}{*}{0.5} & $51-53(0.67)$ & \multirow[t]{3}{*}{4.18} & \multirow[t]{3}{*}{297} & \multirow[t]{3}{*}{0.0} & $49-53(0.22)$ \\
\hline & & & & & $52-53(0.19)$ & & & & $42-54(0.66)$ \\
\hline & & 4.26 & 291 & 0.0 & $49-53(0.70)$ & & & & \\
\hline \multirow[t]{2}{*}{270} & \multirow[t]{2}{*}{283} & \multirow[t]{2}{*}{4.40} & \multirow[t]{2}{*}{282} & \multirow[t]{2}{*}{0.0} & $50-53(0.63)$ & \multirow[t]{2}{*}{4.56} & \multirow[t]{2}{*}{271} & \multirow[t]{2}{*}{0.01} & $49-53(0.63)$ \\
\hline & & & & & $\begin{array}{l}51-5(0.13) \\
52-54(0.27)\end{array}$ & & & & $50-54(-0.17)$ \\
\hline \multirow[t]{5}{*}{240} & \multirow[t]{5}{*}{249} & \multirow[t]{2}{*}{4.92} & \multirow[t]{2}{*}{252} & \multirow[t]{2}{*}{0.0} & $48-53(0.44)$ & 4.75 & \multirow[t]{5}{*}{262} & \multirow[t]{2}{*}{0.1} & $48-53(0.22)$ \\
\hline & & & & & $52-54(0.36)$ & & & & $52-55(0.66)$ \\
\hline & & 5.00 & 248 & 0.1 & $48-53(0.32)$ & & & & \\
\hline & & & & & $52-54(0.52)$ & & & & \\
\hline & & & & & $50-53(0.24)$ & & & & \\
\hline 227 & & & & & & & & & \\
\hline
\end{tabular}



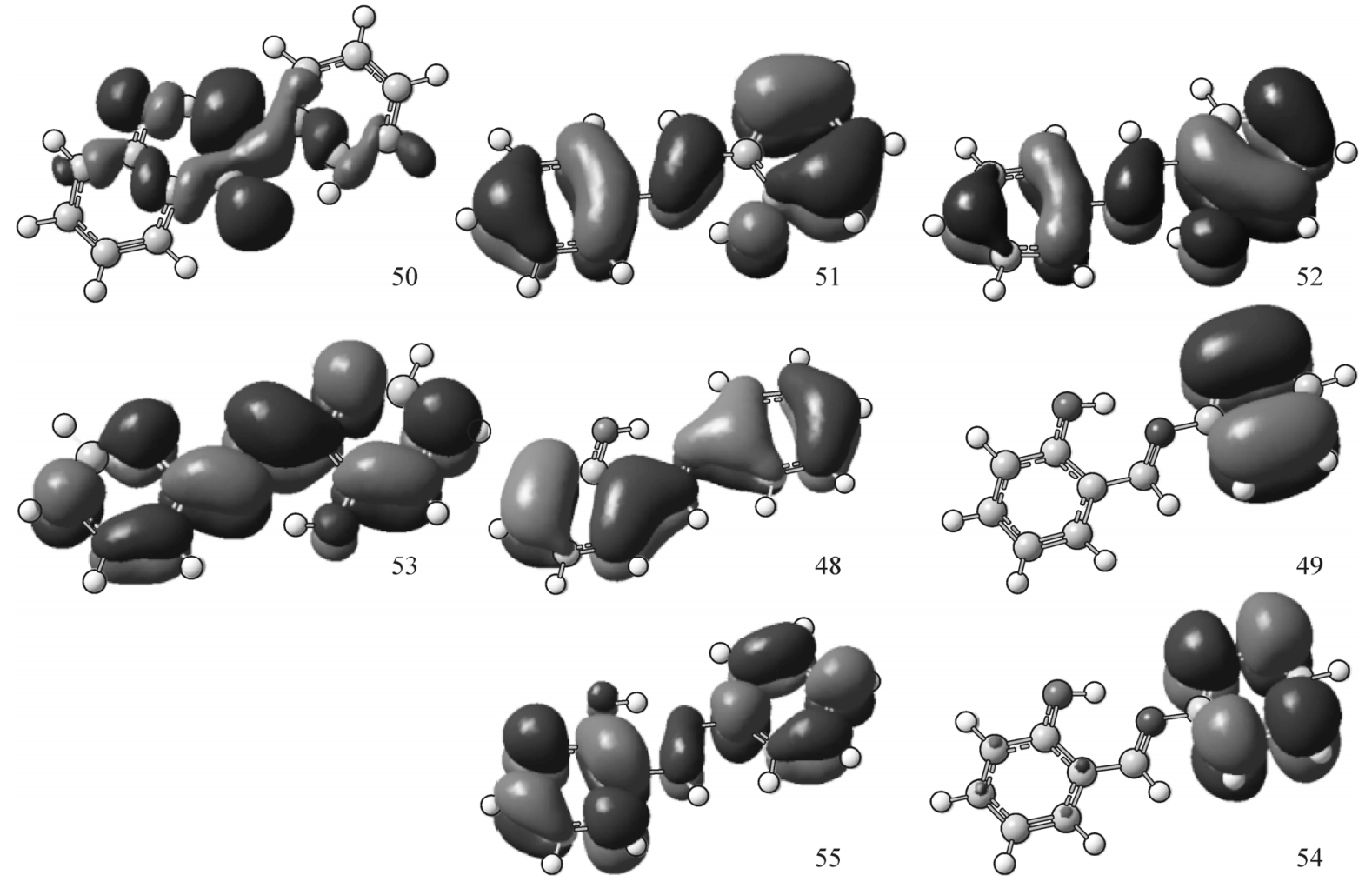

Fig. 2. MOs involved in the electronic states of SA. (52 and 53 represent HOMO and LUMO, respectively)

in these two configurations are displayed in Fig. 2. Three MOs involved are the delocalized $\pi$ orbitals, and hence, the respective transition band corresponds to a typical $\pi \pi^{*}$ state. The second transition appears as a diffuse overlapping band observed at $322 \mathrm{~nm}$. This transition is not predicted theoretically for the trans-enol structure.

The third transition is observed at 305 and is predicted theoretically at $304 \mathrm{~nm}$. The same two configurations $51 \rightarrow 53(0.67)$ and $52 \rightarrow 53(0.19)$ contribute to the $S_{3}$ state indicating its $\pi \pi^{*}$ nature. The fourth band is observed in the $280-270 \mathrm{~nm}$ range and is predicted theoretically at $282 \mathrm{~nm}$. There is only one configuration contributing to the $S_{4}$ state. This configuration is $49 \rightarrow 53(0.70)$. MO 49 is localized completely on the $N$-phenyl moiety, whereas vacant MO 53 is a delocalized orbital. Therefore, the $S_{4}$ state is $\pi \pi^{*}$ involving a considerable charge transfer character. This charge transfer takes place against the dipole moment vector, and consequently, the corresponding excited state $S_{4}$ has a lower dipole moment, and hence, is much less polarized. This would suggest that polar solvents stabilize the more polar ground state to a greater extent and thus cause a red shift of the observed band maxima. The fifth excited state $S_{5}$ is observed at $249 \mathrm{~nm}$ and predicted theoretically at $252 \mathrm{~nm}$. The correspondence is excellent.

An increase in the solvent polarity has but little effect on the spectrum of SA. Thus, the first absorption band suffers a blue shift of $8 \mathrm{~nm}$ whilst the second band suffers a red shift by almost the same amount. This increases the overlap between the two bands. This small solvent effect is expected in view of the similar polarities of both ground and excited states for these two transitions. Furthermore, there seems to be a general trend of enhancing intensity with increasing solvent polarity. Table 1 presents a comparison between the experimentally observed and theoretically computed spectral characteristics of SA.

Although the present high level TDDFT calculations are able to predict well all the observed transitions, yet the second $322 \mathrm{~nm}$ band is not predicted theoretically at all. This might suggest the presence of another absorbing species in the solution, presumably a cis-keto form of SA. Table 1 displays the computed spectral band positions and intensities of the cis-keto form of SA. This form seems to 
have long wavelength $\pi \pi^{*}$ absorption bands at $418 \mathrm{~nm}$ which are not observed in the experimental spectra. The second S2 transition predicted theoretically at $317 \mathrm{~nm}$ is in good correspondence with the observed $322 \mathrm{~nm}$ band. However, the correspondence in the short wavelength region seems much less satisfactory than that of the enol form.

T a b l e 2

Second order perturbation interaction energy values computed in the NBO basis for SA and some of its derivatives

\begin{tabular}{|c|c|c|c|c|c|}
\hline Compound & Donor orbital & Acceptor orbital & $E^{(2)}, \mathrm{kcal} / \mathrm{mol}$ & NBO & Population \\
\hline SA & $\begin{array}{l}\mathrm{C} 1-\mathrm{N} 3 \\
\mathrm{C} 4-\mathrm{C} 5 \\
\mathrm{C} 15-\mathrm{C} 17 \\
\mathrm{LP}(1) \mathrm{N} 3 \\
\mathrm{LP}(2) \mathrm{O} 25 \\
{ }^{*} \mathrm{C} 1-\mathrm{N} 3 \\
{ }^{*} \mathrm{C} 1-\mathrm{N} 3 \\
\mathrm{C} 17-\mathrm{O} 25 \\
\mathrm{LP}(3) \mathrm{O} 25 \\
\end{array}$ & 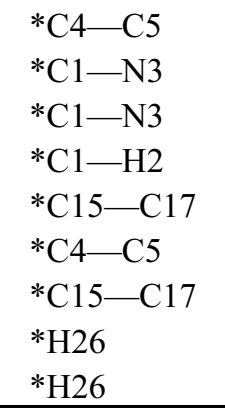 & $\begin{array}{r}13.68 \\
15.15 \\
22.61 \\
11.62 \\
37.10 \\
47.59 \\
136.02 \\
17.84 \\
456.60 \\
\end{array}$ & $\begin{array}{l}\mathrm{C} 15-\mathrm{C} 17 \\
\mathrm{C} 16-\mathrm{C} 18 \\
\mathrm{C} 20-\mathrm{C} 21 \\
\mathrm{LP}(1) \mathrm{N} 3 \\
\mathrm{LP}(2) \mathrm{O} 25 \\
\mathrm{LP}(3) \mathrm{O} 25\end{array}$ & $\begin{array}{l}1.5666 \\
1.7081 \\
1.6965 \\
1.8643 \\
1.8103 \\
1.5647\end{array}$ \\
\hline$o-\mathrm{NO}_{2}$ & $\begin{array}{l}\mathrm{C} 14-\mathrm{C} 15 \\
{ }^{*} \mathrm{C} 1-\mathrm{N} 3 \\
\mathrm{C} 16-\mathrm{O} 24 \\
\mathrm{LP}(1) \mathrm{N} 3 \\
\mathrm{LP}(1) \mathrm{O} 24 \\
\mathrm{LP}(3) \mathrm{O} 24\end{array}$ & $\begin{array}{l}{ }^{*} \mathrm{C} 1-\mathrm{N} 3 \\
* \mathrm{C} 14-\mathrm{C} 15 \\
* \mathrm{H} 25 \\
{ }^{*} \mathrm{H} 25 \\
* \mathrm{H} 25 \\
* \mathrm{H} 25\end{array}$ & $\begin{array}{r}25.91 \\
139.93 \\
17.50 \\
32.53 \\
15.03 \\
475.69 \\
\end{array}$ & $\begin{array}{l}\mathrm{C} 4-\mathrm{C} 5 \\
\mathrm{C} 6-\mathrm{C} 9 \\
\mathrm{C} 14-\mathrm{C} 15 \\
\mathrm{C} 16-\mathrm{C} 19 \\
\mathrm{C} 17-\mathrm{C} 20 \\
\mathrm{LP}(3) \mathrm{O} 24\end{array}$ & $\begin{array}{l}1.6227 \\
1.6625 \\
1.6352 \\
1.5893 \\
1.6225 \\
1.4371 \\
\end{array}$ \\
\hline$p-\mathrm{NO}_{2}$ & $\begin{array}{l}\mathrm{C} 1-\mathrm{N} 3 \\
\mathrm{C} 1-\mathrm{N} 3 \\
\mathrm{C} 4-\mathrm{C} 6 \\
\mathrm{C} 14-\mathrm{C} 15 \\
\mathrm{LP}(1) \mathrm{N} 3 \\
\mathrm{LP}(2) \mathrm{O} 24 \\
{ }^{*} \mathrm{C} 1-\mathrm{N} 3 \\
{ }^{*} \mathrm{C} 1-\mathrm{N} 3 \\
\mathrm{C} 16-\mathrm{O} 24\end{array}$ & $\begin{array}{l}\mathrm{C} 4-\mathrm{C} 6 \\
\mathrm{C} 14-\mathrm{C} 15 \\
{ }^{*} \mathrm{C} 1-\mathrm{N} 3 \\
{ }^{*} \mathrm{C} 1-\mathrm{N} 3 \\
{ }^{*} \mathrm{C} 1-\mathrm{H} 2 \\
{ }^{*} \mathrm{C} 16-\mathrm{C} 19 \\
{ }^{*} \mathrm{C} 4-\mathrm{C} 6 \\
{ }^{*} \mathrm{C} 14-\mathrm{C} 15 \\
{ }^{*} \mathrm{H} 25\end{array}$ & $\begin{array}{r}10.78 \\
7.09 \\
7.77 \\
26.18 \\
10.99 \\
35.87 \\
92.72 \\
124.98 \\
17.51 \\
\end{array}$ & $\begin{array}{l}\mathrm{C} 4-\mathrm{C} 6 \\
\mathrm{C} 5-\mathrm{C} 7 \\
\mathrm{C} 9-\mathrm{C} 11 \\
\mathrm{C} 5-\mathrm{C} 7 \\
\mathrm{C} 9-\mathrm{C} 11 \\
\mathrm{C} 14-\mathrm{C} 15 \\
\mathrm{C} 17-\mathrm{C} 20 \\
\mathrm{LP}(3) \mathrm{O} 24\end{array}$ & $\begin{array}{l}1.60999 \\
1.6669 \\
1.6438 \\
1.6669 \\
1.6437 \\
1.6305 \\
1.6158 \\
1.5532\end{array}$ \\
\hline$o-\mathrm{OCH}_{3}$ & $\begin{array}{l}\mathrm{C} 1-\mathrm{N} 3 \\
\mathrm{C} 4-\mathrm{C} 6 \\
\mathrm{C} 12-\mathrm{C} 14 \\
\mathrm{LP}(2) \mathrm{O} 22 \\
{ }^{*} \mathrm{C} 1-\mathrm{N} 3\end{array}$ & $\begin{array}{l}{ }^{* \mathrm{C} 4} 4-\mathrm{C} 6 \\
{ }^{*} \mathrm{C} 1-\mathrm{N} 3 \\
{ }^{*} \mathrm{C} 1-\mathrm{N} 3 \\
{ }^{*} \mathrm{C} 12-\mathrm{C} 14 \\
{ }^{*} \mathrm{C} 4-\mathrm{C} 6\end{array}$ & $\begin{array}{r}15.25 \\
10.61 \\
22.09 \\
37.00 \\
131.01\end{array}$ & $\begin{array}{l}\mathrm{C} 4-\mathrm{C} 6 \\
\mathrm{C} 5-\mathrm{C} 7 \\
\mathrm{C}-8-\mathrm{C} 9 \\
\mathrm{C} 17-\mathrm{C} 18 \\
\mathrm{LP}(3) \mathrm{O} 22\end{array}$ & $\begin{array}{l}1.6197 \\
1.6759 \\
1.6712 \\
1.6991 \\
1.5696\end{array}$ \\
\hline$p-\mathrm{OCH}_{3}$ & $\begin{array}{l}\mathrm{C} 1-\mathrm{N} 3 \\
\mathrm{C} 4-\mathrm{C} 5 \\
\mathrm{C} 14-\mathrm{C} 16 \\
\mathrm{LP}(1) \mathrm{N} 3 \\
\mathrm{LP}(2) \mathrm{O} 24 \\
* \mathrm{C} 1-\mathrm{N} 3 \\
* \mathrm{C} 1-\mathrm{N} 3 \\
\mathrm{C} 16-\mathrm{C} 24 \\
\mathrm{LP}(1) \mathrm{N} 3 \\
\mathrm{LP}(1) \mathrm{O} 24 \\
\mathrm{LP}(3) \mathrm{O} 24\end{array}$ & $\begin{array}{l}* \mathrm{C} 4-\mathrm{C} 5 \\
* \mathrm{C} 1-\mathrm{N} 3 \\
* \mathrm{C} 1-\mathrm{N} 3 \\
* \mathrm{C} 1-\mathrm{H} 2 \\
* \mathrm{C} 14-\mathrm{C} 16 \\
* \mathrm{C} 4-\mathrm{C} 5 \\
* \mathrm{C} 14-\mathrm{C} 16 \\
* \mathrm{LPH} 25 \\
* \mathrm{LPH} 25 \\
* \mathrm{LPH} 25 \\
\mathrm{LP}(1) \mathrm{H} 25\end{array}$ & $\begin{array}{c}10.43 \\
11.75 \\
21.70 \\
11.31 \\
16.50 \\
45.49 \\
172.86 \\
17.63 \\
37.18 \\
14.4 \\
459.78\end{array}$ & $\begin{array}{l}\mathrm{C} 4-\mathrm{C} 5 \\
\mathrm{C} 6-\mathrm{C} 9 \\
\mathrm{C} 7-\mathrm{C} 11 \\
\mathrm{C} 14-\mathrm{C} 16 \\
\mathrm{C} 15-\mathrm{C} 17 \\
\mathrm{C} 19-\mathrm{C} 20 \\
\mathrm{LP}(3) \mathrm{O} 24\end{array}$ & $\begin{array}{l}1.6429 \\
1.7209 \\
1.6562 \\
1.5717 \\
1.7062 \\
1.6969 \\
1.5616\end{array}$ \\
\hline
\end{tabular}


The present study focuses on the effect of substituents on the electronic and vibrational spectra of SA. In order to fulfill this goal it is instructive to analyze and discuss the NBO results for SA. The NBO analysis provides the electron density distribution on atoms and in bonding regions. By comparing a set of molecules you can, for instance, see the donor or acceptor effect of the substituent. Table 2 presents the most relevant perturbation interactions within the natural orbitals of SA. In this table, the reported relevant interaction values are $\geq 10 \mathrm{kcal} / \mathrm{mol}$. Careful inspections of the data in this table reveals that:

1. The $\mathrm{C}-\mathrm{N} \pi$ orbital interacts equally well with both phenyl rings. In fact, its interaction with the $\mathrm{OH}-\mathrm{Ph}$ ring is greater. Furthermore, the lone pair orbital of the nitrogen atom enjoys hyperconjugation with the $\mathrm{C}_{1}-\mathrm{H}_{2}$ orbital.

2. The oxygen lone pair orbital, on the other hand, interacts essentially with the $\pi$ framework of the phenyl ring. The interaction of the oxygen atom lone pair orbitals with the hydrogen virtual and Rydberg orbitals is pronounced.

3. It is surprising to notice a decrease in the population of the NBO $\mathrm{C}_{15}-\mathrm{C}_{17}, \mathrm{C}_{16}-\mathrm{C}_{18}$, and $\mathrm{C}_{20}-\mathrm{C}_{21}$ reflecting a charge transfer away from the phenyl ring. This is also evident in the case of the population of the oxygen lone orbital LP(3), which is reduced by almost $0.5 \mathrm{e}$.

In conclusion, SA enjoys the linear conjugation that is responsible for the observed spectrum. No specific part of the molecule manifests itself in the observed spectrum due to the extended $\pi$ system. The interaction between the oxygen and hydrogen atomic orbitals is of a covalent character, and thus, a proton transfer toward the nitrogen atom would be opposed by a high energy barrier.

It would be reasonable at this point to analyze and discuss the vibrational spectrum of SA. Fig. 3 displays the FTIR spectrum of SA measured as a $\mathrm{KBr}$ pellet. The spectrum is composed of three main regions. A broad low intensity envelope spans the $3600-3200 \mathrm{~cm}^{-1}$ range. This envelope encloses the aromatic symmetric and asymmetric $\mathrm{CH}$ stretching and $\mathrm{OH}$ stretching modes. The middle region is of much higher intensity and is composed of several intense sharp absorption peaks corresponding to the aromatic ring vibration and the $\mathrm{C}=\mathrm{N}$ stretching mode that can be identified at $1613 \mathrm{~cm}^{-1}$. The third

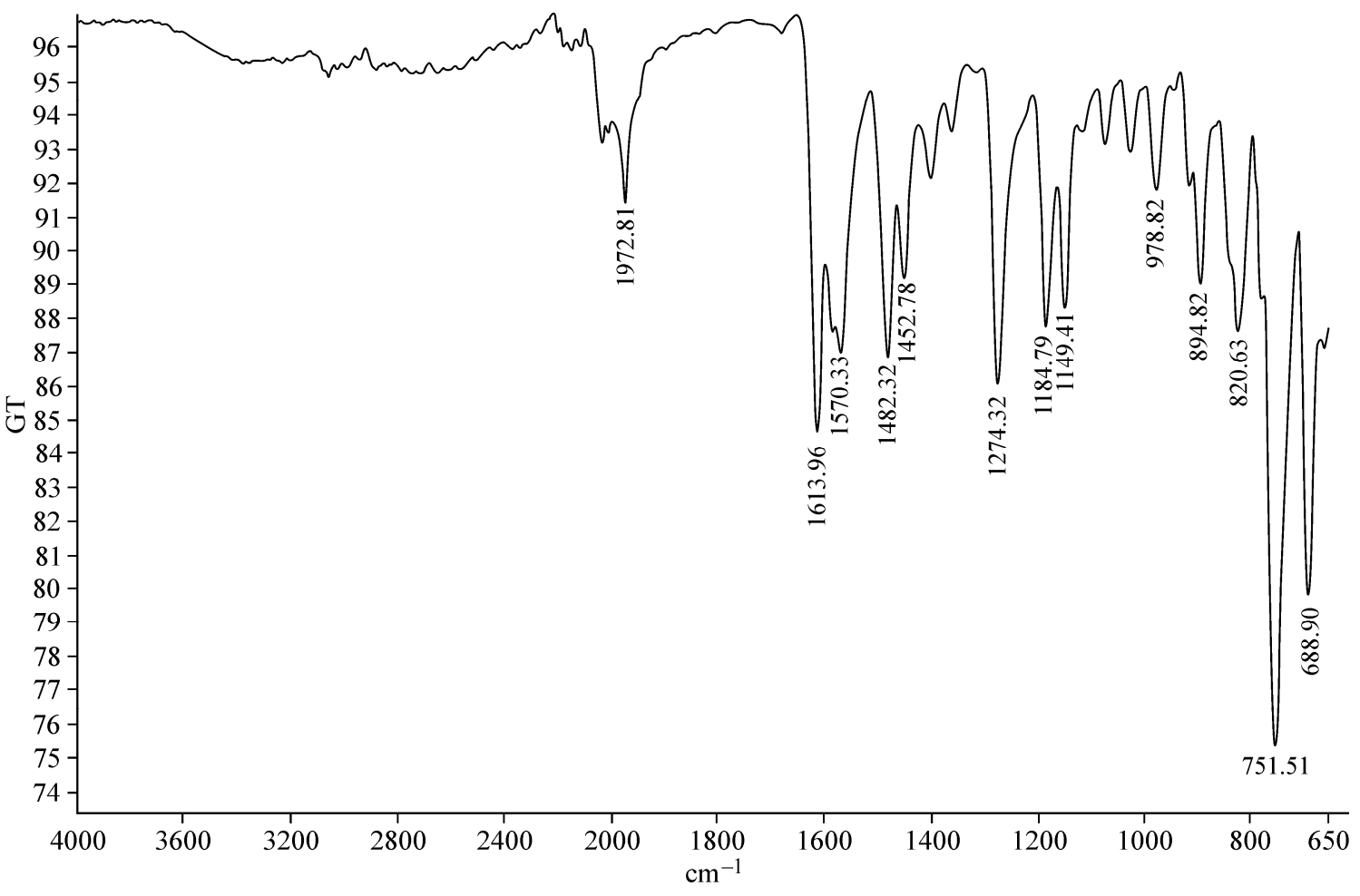

Fig. 3. FTIR spectrum of SA measured in the KBr pellet 
region spans the $1000-500 \mathrm{~cm}^{-1}$ range and is composed of several sharp peaks of variable intensities corresponding to the coupling and combination bands.

A comparison of the experimentally observed and theoretically computed vibrational bands is given in Table 4 along with their assignments. In the present discussion, we select one band from each of the three regions. The selected bands correspond to the main functional groups characterizing the $\mathrm{SA}$ framework, namely, $\mathrm{OH}, \mathrm{C}=\mathrm{N}$, and the aromatic ring where substituents will be introduced. Thus, in this part and the subsequent discussion, we focus on three bands which can be considered as "IR marker bands" for SA. These are the $\mathrm{OH}$ stretching predicted as strong (relative intensity 334) at $3175 \mathrm{~cm}^{-1}$, the $\mathrm{C}=\mathrm{N}$ stretching and coupling vibrational band of the $\mathrm{C}=\mathrm{N}$ vibrational mode, which is observed and predicted in the $1600 \mathrm{~cm}^{-1}$ region, and the phenyl ring breathing modes observed at $750 \mathrm{~cm}^{-1}$ and predicted at $860 \mathrm{~cm}^{-1}$.

Substituent effect. The substituted SA derivatives studied in the present work are presented in Scheme 2. Two sets of substituents have been considered. A set of electron withdrawing substituents, namely $-\mathrm{Cl},-\mathrm{Br}$, and $-\mathrm{NO}_{2}$ substituted in the ortho- and para-positions of the $\mathrm{N}-\mathrm{Ph}$ moiety. Another set is composed of three electron donating substituents, namely, $-\mathrm{OH},-\mathrm{NH}_{2}$, and $-\mathrm{OCH}_{3}$ also substituted in both ortho- and para-positions. The choice of these substituents aims to create a push-pull system on the SA basic structure, which hopefully would shade light onto its photo physics.

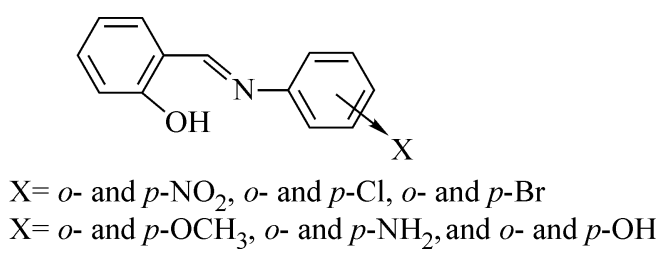

Scheme 2. Series of substituted SA derivatives studied in the present work

Fig. 4 displays the electronic absorption spectra of the $o-\mathrm{Cl}, o-\mathrm{Br}$, and $o-\mathrm{NO}_{2} \mathrm{SA}$ derivatives, in both ethanol and cyclohexane as solvents. The general features of the spectra resemble those of the parent compound. The perturbation effect of the nitro group seems to be pronounced. Thus, a new absorption band appears at $375 \mathrm{~nm}(\varepsilon=3300)$ while the second and third transitions are now diffuse and appear as low intensity $(\varepsilon=2700)$ shoulders under the short wavelength tail of the new long wavelength band. The main configuration contributing to the first excited state is $63-64$ configuration (0.7).

It is worth noting that the full geometry optimization of the $o$-nito derivative of SA at the $\mathrm{B} 3 \mathrm{LYB} / 611++\mathrm{G}^{* *}$ level of theory reveals the non-coplanrity of the molecule. This is expected due the steric hindrance caused by the presence of a bulky $\mathrm{NO}_{2}$ group in the ortho position. This steric hindrance forces the $\mathrm{Ph}-\mathrm{NO}_{2}$ moiety to be out-of-plane by an angle of $83^{\circ}$. The second order perturbation energy analysis of the $o-\mathrm{NO}_{2}$ derivative (Table 2) reveals a dramatic change in the bonding as compared to parent SA. Thus, the interaction of the $\mathrm{C}_{1}-\mathrm{N}_{3} \mathrm{NBO}$ with the $\pi$ system of the nitrophenyl

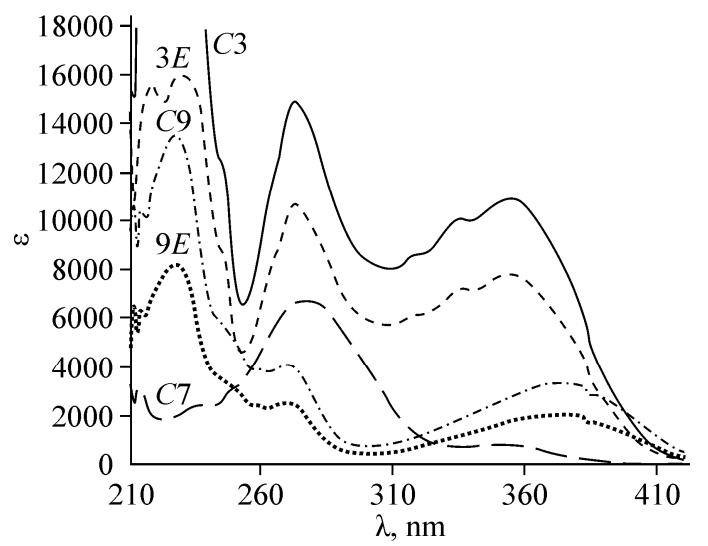
moiety is now reduced to very small values. The interaction of the $\mathrm{C}_{1}-\mathrm{N}_{3}$ NBO with the $\pi$ system of the $o$ hydroxy phenyl moiety is more pronounced. One should also note that a pronounced interaction energy term between the $\mathrm{C}-\mathrm{N}$ nitrogen lone pair orbital and the H25virtual orbital has been observed. Therefore, Table 2 and 4 data and the electronic spectra of the $o$-nitro phenyl derivative reveal that the charge redistributions

Fig. 4. Electronic absorption spectra of (3) $o-\mathrm{Cl}$, (7) $o-\mathrm{Br}$, and (9) $o-\mathrm{NO}_{2}$ measured in cyclohexane $(C)$ and ethanol $(E)$ as solvents 

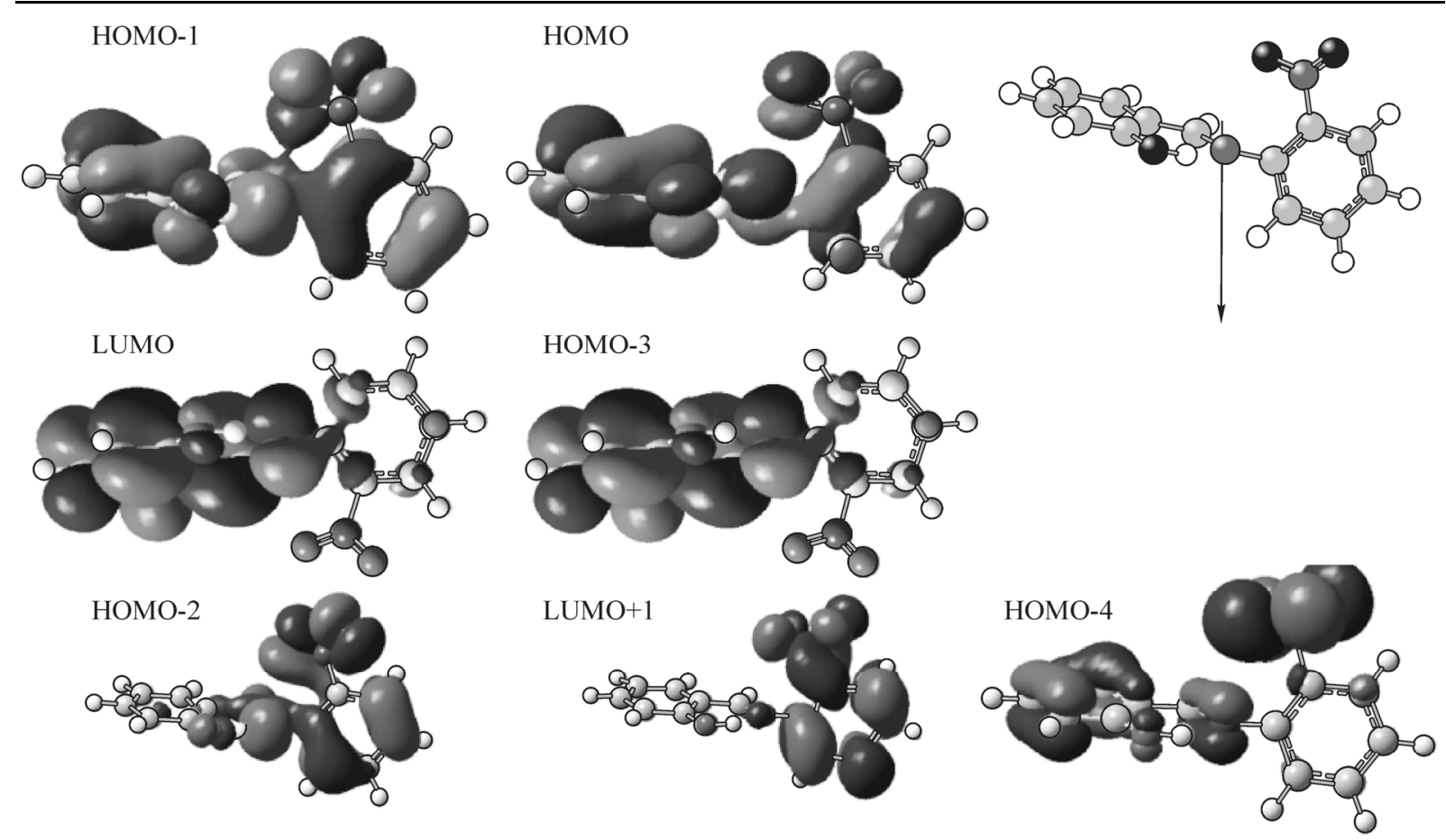

Fig. 5. Fully optimized geometry of the $o-\mathrm{NO}_{2}$ derivative of SA and MOs involved in the electronic transitions

might facilitate and lower the potential energy barrier for the proton transfer from the $\mathrm{OH}$ group to the nitrogen atom of the $\mathrm{C}-\mathrm{N}$ group leading to a keto structure. There is also a reduction in the population of the NBO's of the phenyl moiety due to the strong withdrawing effect of the nitro group.

Fig. 5 displays the optimized geometric structure of the $o$-nitro derivatives and some of the molecular orbitals involved in the electronic transitions. The first excited state is composed of one configuration 63-64. HOMO 63 is a delocalized MO (in spite of the non-coplanarity of the molecule) whereas LUMO 64 is localized over the $\mathrm{Ph}-\mathrm{OH}$ moiety. Therefore, the long wavelength band is a $\pi \pi^{*}$ transition having a charge transfer character. The second and third excited states each involve three configurations; all involve the charge transfer to the $\mathrm{Ph}-\mathrm{OH}$ moiety (Table 2). The electronic absorption spectrum of the $o$-Cl derivative of SA resembles to a great extent that of parent SA. However, all observed bands exhibit a marked increase in the intensity. This molecule demonstrates coplanarity. The general features of the spectrum of the $o$ - $\mathrm{Br}$ derivative, on the other hand, are different. Thus, there is a considerable reduction in the intensity and a blue shift in the position of the long wavelength absorption band and a considerable intensification of the $275 \mathrm{~nm}$ band. The second and third bands (in the 320-290 nm region) are not observed in the spectrum of the $o$-Br derivative.

The vibrational spectrum of the $o-\mathrm{NO}_{2}$ derivative of SA reflects the major geometry changes introduced by the nitro group. Thus, the $o-\mathrm{NO}_{2}$ group seems to have a marked effect on SA IR marker bands. Thus, the $\mathrm{OH}$ stretching vibration is shifted to $3316 \mathrm{~cm}^{-1}$ and is intensified. The $\mathrm{C}=\mathrm{N}$ stretching mode suffers also the same trend where it is shifted to $1680 \mathrm{~cm}^{-1}$ and is considerably intensified. The $\mathrm{C}=\mathrm{N}$ and phenyl ring breathing combination band shows also the same trend (Table 4). This same trend of shifting to higher wavenumbers and the intensification of the three IR marker bands are observed for $o$ - $\mathrm{Br}$ and $o$-Cl derivatives. Fig. 6 displays the FTIR spectrum of the $o$-Br derivative of SA. The bulk $o-\mathrm{Br}$ group causes the splitting and intensification of the $\mathrm{OH}$ and aromatic $\mathrm{CH}$ stretching modes. These stretching bands are also shifted to longer wavenumber values.

In conclusion, the substitution in the ortho position of the $\mathrm{N}-\mathrm{Ph}$ moiety by electron withdrawing substituents such as $\mathrm{NO}_{2}, \mathrm{Cl}$, and $\mathrm{Br}$ causes non-coplanarity of the SA molecular skeletal structure and all observed $\pi \pi^{*}$ transitions have a considerable charge transfer character in the direction of the $\mathrm{Ph}-\mathrm{NO}_{2}$ moiety. However, these types of substitution do not in general create new transitions, except 


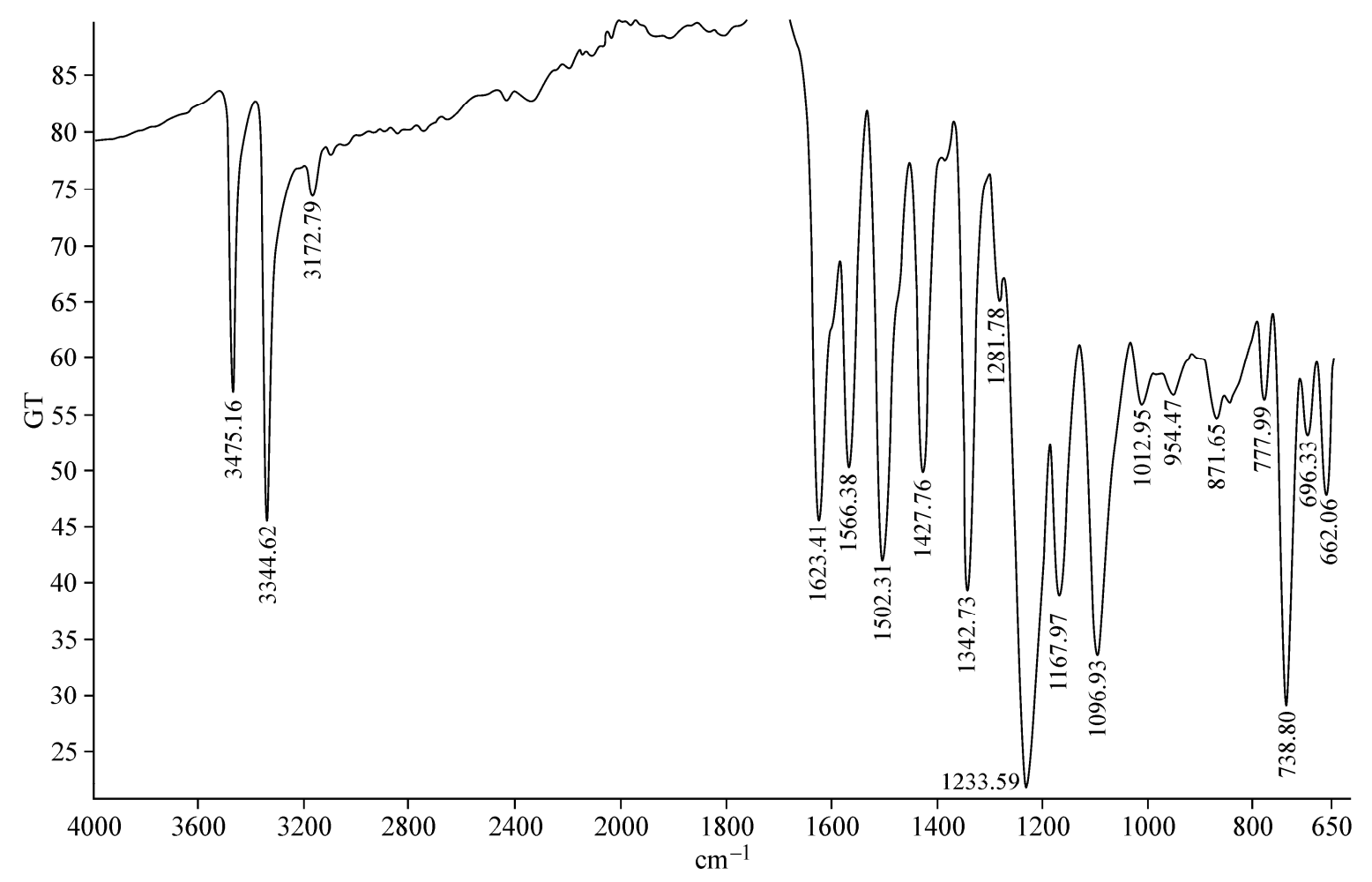

Fig. 6. FTIR spectrum of the $o$-Br derivative of SA measured in the $\mathrm{KBr}$ pellet

the case of the $\mathrm{NO}_{2}$ derivative where a long wavelength band at $380 \mathrm{~nm}$ is observed. Furthermore, electron withdrawing groups in the ortho position also have the general effect of shifting the IR marker bands of SA to higher wavenumbers and appreciably increase their intensities.

The substitution by the same electron withdrawing groups but in the para-position of the $\mathrm{N}-\mathrm{Ph}$ moiety does not introduce as much perturbation as that observed in the case of ortho substitution (Table 3). Thus, the $p-\mathrm{NO}_{2}$ derivative is still non-coplanar, but the dihedral angle between the plane of the $\mathrm{Ph}-\mathrm{NO}_{2}$ moiety and the rest of the molecule is much smaller $\left(38^{\circ}\right)$ than that in the case of the $o-\mathrm{NO}_{2}$ derivative. The origin of the non-coplanarity in the case of the para derivative is the dimensioned charge density accumulation in the $\mathrm{NO}_{2} \mathrm{Ph}-\mathrm{N}$ bond region. The $\mathrm{NO}_{2}$ group acts as an electron sink withdrawing the charge density away from this region. $\mathrm{NBO}$ analysis of the $p-\mathrm{NO}_{2}$ derivative (Table 2) indicates that it retained the extended conjugation of SA as revealed by the interaction of $\mathrm{C}_{1}-\mathrm{N}_{3}$ NBOs with those of both phenyl rings. Furthermore, the interaction of the nitrogen lone orbitals with the hydroxyl group hydrogen atom is marked. Table 3 data indicate that the electronic spectrum, however, resembles to a great extent that of the ortho derivative yet more diffuse and of a lower intensity. The $p$-Br substitution causes a marked red shift of the first absorption band to $356 \mathrm{~nm}$ whilst the second and third bands appear overlapping with the peak maxima at $328 \mathrm{~nm}$ and $312 \mathrm{~nm}$. One should note that the band appearing at $270 \mathrm{~nm}$ in SA seems to be persistent and appears in almost the same region in all derivatives studied. This band is a conjugation band characterizing the SA $\pi$ framework.

Electron withdrawing substituents in the para position do not have the same marked effect noted in the case of the ortho substitution. In fact, the IR marker bands do not show any significant shift in peak positions. However, peak intensities show a reduction in intensities. Nevertheless, the main observation to be made here is the coupling between the $\mathrm{OH}$ and aromatic $\mathrm{CH}$ stretching modes with a consequent reduction in the intensity.

Fig. 7 displays the electronic absorption spectra of the $o-\mathrm{OCH}_{3}$ and $p-\mathrm{OCH}_{3}$ derivatives of $\mathrm{SA}$ in cyclohexane and ethanol as solvents. Electron donating groups cause a marked shift of the electron density onto the $-\mathrm{N}=\mathrm{C}$-phenol moiety. The $o$-methoxy substitution forces the $\mathrm{N}-\mathrm{Ph}$ moiety out of 
T a b l e 3

Experimentally observed and theoretically computed electronic spectral characteristics of SA derivatives studied in the present work

\begin{tabular}{|c|c|c|c|c|c|c|c|c|c|c|c|c|c|}
\hline \multirow{8}{*}{$\begin{array}{c}\begin{array}{c}\text { Com- } \\
\text { pounds }\end{array} \\
2\end{array}$} & \multicolumn{4}{|c|}{ Theoretical } & \multicolumn{2}{|c|}{$\begin{array}{l}\text { Experi- } \\
\text { mental }\end{array}$} & \multirow{2}{*}{$\begin{array}{c}\text { Com- } \\
\text { pounds }\end{array}$} & \multicolumn{4}{|c|}{ Theoretical } & \multicolumn{2}{|c|}{$\begin{array}{l}\text { Experi- } \\
\text { mental }\end{array}$} \\
\hline & \multicolumn{2}{|c|}{$\begin{array}{l}\text { Molecular orbital } \\
\text { contribution }\end{array}$} & \multirow{2}{*}{$\begin{array}{c}\lambda, \mathrm{nm} \\
385\end{array}$} & \multirow{3}{*}{\begin{tabular}{|l}
\multicolumn{1}{|r}{$f$} \\
0.3 \\
0.01
\end{tabular}} & \multirow{2}{*}{\begin{tabular}{|c|}
$\lambda_{\mathrm{e}}$ \\
362 \\
\end{tabular}} & \multirow{2}{*}{\begin{tabular}{|c|}
$\lambda_{\mathrm{c}}$ \\
366
\end{tabular}} & & \multicolumn{2}{|c|}{$\begin{array}{l}\text { Molecular orbital } \\
\text { contribution }\end{array}$} & \multirow{2}{*}{$\begin{array}{r}\lambda, \mathrm{nm} \\
360\end{array}$} & \multirow{2}{*}{$\begin{array}{r}f \\
0.43\end{array}$} & \multirow{2}{*}{$\begin{array}{c}\lambda_{\mathrm{e}} \\
346\end{array}$} & \multirow{2}{*}{$\begin{array}{c}\lambda_{\mathrm{c}} \\
347\end{array}$} \\
\hline & $\mathrm{H} \rightarrow \mathrm{L}$ & 0.69964 & & & & & 8 & $\mathrm{H} \rightarrow \mathrm{L}$ & 0.67771 & & & & \\
\hline & $\mathrm{H}-4 \rightarrow \mathrm{L}$ & 0.62101 & 332 & & \multirow{3}{*}{318} & \multirow{3}{*}{319} & & $\mathrm{H}-1 \rightarrow \mathrm{L}$ & 0.66816 & 313 & 0.47 & & \\
\hline & $\mathrm{H}-1 \rightarrow \mathrm{L}$ & 0.6778 & 329 & 0.5 & & & & $\mathrm{H}-4 \rightarrow \mathrm{L}+1$ & 0.70268 & 290 & 0.0001 & \multirow[b]{3}{*}{267} & \multirow{4}{*}{$\begin{array}{l}266 \\
231\end{array}$} \\
\hline & $\mathrm{H}-1 \rightarrow \mathrm{L}+1$ & 0.63103 & 310 & 0.02 & & & & $\mathrm{H} \rightarrow \mathrm{L}+1$ & 0.47585 & 279 & 0.01 & & \\
\hline & $\mathrm{H}-2 \rightarrow \mathrm{L}+1$ & 0.49278 & 295 & 0.04 & 227 & 228 & & $\mathrm{H}-3 \rightarrow \mathrm{L}+1$ & 0.56654 & 258 & 0.01 & & \\
\hline & $\mathrm{H}-3 \rightarrow \mathrm{L}+1$ & 0.57715 & 290 & 0.01 & 219 & 220 & & $\mathrm{H} \rightarrow \mathrm{L}+2$ & 0.49281 & 254 & 0.07 & 230 & \\
\hline \multirow[t]{8}{*}{3} & & & & & 385 & 355 & \multirow[t]{8}{*}{9} & $\mathrm{H} \rightarrow \mathrm{L}$ & 0.69784 & 381 & 0.01 & 371 & 372 \\
\hline & & & & & 354 & 334 & & $\mathrm{H}-1 \rightarrow \mathrm{L}$ & 0.60003 & 346 & 0.043 & & \\
\hline & $\mathrm{H} \rightarrow \mathrm{L}$ & 0.66692 & 334 & 0.30 & 333 & 232 & & $\mathrm{H} \rightarrow \mathrm{L}+1$ & 0.63254 & 320 & 0.13 & & \\
\hline & $\mathrm{H}-1 \rightarrow \mathrm{L}$ & 0.66105 & 316 & 0.01 & & & & $\mathrm{H}-3 \rightarrow \mathrm{L}$ & 0.44848 & 319 & 0.003 & & \\
\hline & $\mathrm{H}-2 \rightarrow \mathrm{L}$ & 0.62149 & 279 & 0.01 & 272 & 272 & & $\mathrm{H}-2 \rightarrow \mathrm{L}$ & 0.6417 & 307 & 0.003 & & \\
\hline & $\mathrm{H}-3 \rightarrow \mathrm{L}$ & 0.57736 & 261 & 0.30 & & & & $\mathrm{H}-2 \rightarrow \mathrm{L}+1$ & 0.66115 & 303 & 0.015 & & \\
\hline & $\mathrm{H} \rightarrow \mathrm{L}+1$ & 0.63134 & 253 & 0.02 & & & & & & & & 267 & 269 \\
\hline & $\mathrm{H}-1 \rightarrow \mathrm{L}+1$ & 0.57893 & 239 & 0.02 & 228 & 229 & & & & & & 225 & 227 \\
\hline 4 & $\mathrm{H} \rightarrow \mathrm{L}$ & 0.69393 & 354 & 0.60 & 385 & 359 & 10 & $\mathrm{H} \rightarrow \mathrm{L}$ & 0.67988 & 349 & 0.33 & 359 & 369 \\
\hline & $\mathrm{H}-1 \rightarrow \mathrm{L}$ & 0.68269 & 318 & 0.04 & 334 & 333 & & $\mathrm{H}-2 \rightarrow \mathrm{L}$ & 0.69732 & 323 & 0.0001 & 334 & 335 \\
\hline & $\mathrm{H} \rightarrow \mathrm{L}+2$ & 0.54786 & 279 & 0.02 & & & & $\mathrm{H}-1 \rightarrow \mathrm{L}$ & 0.66737 & 298 & 0.50 & & \\
\hline & $\mathrm{H}-4 \rightarrow \mathrm{L}$ & 0.46621 & 270 & 0.20 & 270 & 272 & & $\mathrm{H}-3 \rightarrow \mathrm{L}$ & 0.55166 & 279 & 0.002 & & \\
\hline & $\mathrm{H}-4 \rightarrow \mathrm{L}$ & 0.43115 & 255 & 0.01 & 293 & 296 & & $\mathrm{H} \rightarrow \mathrm{L}+1$ & 0.57345 & 254 & 0.04 & 263 & 265 \\
\hline & $\mathrm{H}-3 \rightarrow \mathrm{L}$ & 0.5335 & 252 & 0.05 & 224 & 227 & & $\mathrm{H}-5 \rightarrow \mathrm{L}$ & 0.66735 & 248 & 0.00 & & 227 \\
\hline 5 & $\mathrm{H} \rightarrow \mathrm{L}$ & 0.6889 & 349 & 0.40 & 349 & 353 & 11 & $\mathrm{H} \rightarrow \mathrm{L}$ & 0.69666 & 372 & 0.75 & 364 & 365 \\
\hline & $\mathrm{H}-1 \rightarrow \mathrm{L}$ & 0.68264 & 320 & 0.01 & 329 & & & $\mathrm{H}-1 \rightarrow \mathrm{L}$ & 0.67978 & 322 & 0.05 & 326 & \\
\hline & $\mathrm{H}-2 \rightarrow \mathrm{L}$ & 0.59137 & 290 & 0.02 & & & & $\mathrm{H} \rightarrow \mathrm{L}+1$ & 0.63693 & 294 & 0.04 & & \\
\hline & $\mathrm{H}-3 \rightarrow \mathrm{L}$ & 0.54747 & 270 & 0.30 & 269 & 270 & & $\mathrm{H}-4 \rightarrow \mathrm{L}$ & 0.70233 & 284 & 0.0001 & & \\
\hline & $\mathrm{H} \rightarrow \mathrm{L}+1$ & 0.60048 & 252 & 0.02 & & & & $\mathrm{H} \rightarrow \mathrm{L}+2$ & 0.69382 & 278 & 0.002 & & \\
\hline & $\mathrm{H} \rightarrow \mathrm{L}+2$ & 0.58548 & 243 & 0.09 & 225 & 228 & & $\mathrm{H} \rightarrow \mathrm{L}+3$ & 0.53052 & 267 & 0.04 & 265 & 266 \\
\hline 6 & $\mathrm{H} \rightarrow \mathrm{L}$ & 0.67877 & 361 & 0.46 & 353 & 355 & & & & & & 229 & 230 \\
\hline & $\mathrm{H}-1 \rightarrow \mathrm{L}$ & 0.67028 & 316 & 0.45 & 328 & 329 & 12 & $\mathrm{H} \rightarrow \mathrm{L}$ & 0.67693 & 349 & 0.39 & & \\
\hline & $\mathrm{H}-4 \rightarrow \mathrm{L}$ & 0.70143 & 291 & 0.001 & 310 & 313 & & $\mathrm{H}-1 \rightarrow \mathrm{L}$ & 0.64759 & 307 & 0.26 & & \\
\hline & $\mathrm{H} \rightarrow \mathrm{L}+1$ & 0.4764 & 280 & 0.01 & 272 & 273 & & $\mathrm{H}-2 \rightarrow \mathrm{L}$ & 0.61882 & 285 & 0.24 & & \\
\hline & $\mathrm{H}-2 \rightarrow \mathrm{L}$ & 0.55738 & 262 & 0.04 & & & & $\mathrm{H}-3 \rightarrow \mathrm{L}$ & 0.70225 & 292 & 0.00 & & \\
\hline & $\mathrm{H} \rightarrow \mathrm{L}+1$ & 0.50277 & 254 & 0.07 & 230 & 232 & & $\mathrm{H} \rightarrow \mathrm{L}+1$ & 0.58127 & 256 & 0.03 & 265 & 266 \\
\hline 7 & $\mathrm{H} \rightarrow \mathrm{L}$ & 0.68297 & 357 & 0.31 & 345 & 350 & & $\mathrm{H} \rightarrow \mathrm{L}+2$ & 0.67465 & 251 & 0.001 & 252 & \\
\hline & $\mathrm{H}-3 \rightarrow \mathrm{L}$ & 0.69869 & 306 & 0.0001 & & & & & & & & 223 & 224 \\
\hline & $\mathrm{H}-1 \rightarrow \mathrm{L}$ & 0.66536 & 305 & 0.50 & & & & & & & & & \\
\hline & $\mathrm{H}-2 \rightarrow \mathrm{L}$ & 0.62409 & 291 & 0.08 & & & & & & & & & \\
\hline & $\mathrm{H} \rightarrow \mathrm{L}+2$ & 0.66453 & 263 & 0.46 & 275 & 277 & & & & & & & \\
\hline & $\mathrm{H} \rightarrow \mathrm{L}+1$ & 0.64169 & 259 & 0.05 & 233 & 234 & & & & & & & \\
\hline
\end{tabular}

* Only main configurations. 


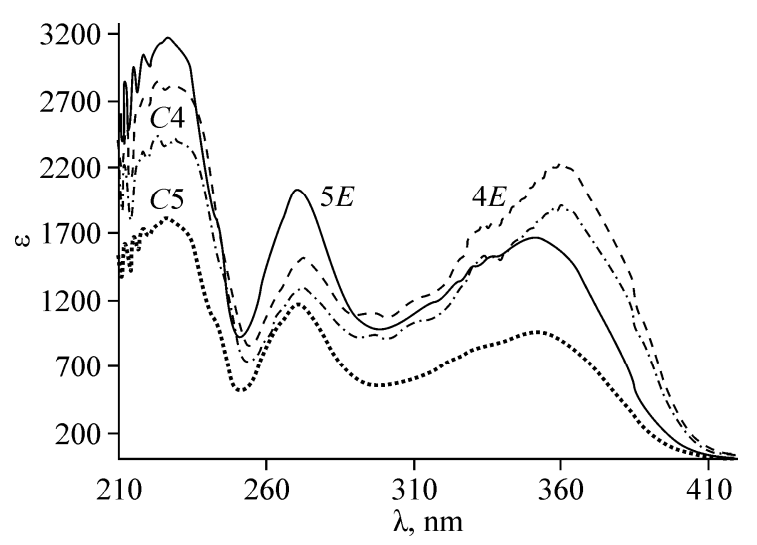

Fig. 7. Electronic absorption spectra of the (4) $-\mathrm{O}-\mathrm{OCH}_{3}$ and (5) $p-\mathrm{OCH}_{3} \mathrm{SA}$ derivatives measured in cyclohexane $(C)$ and ethanol $(E)$ as solvents with $69-70(0.7)$ as the main configuration. Thus, as Table 3 indicates, this transition corresponds to a $\pi \pi^{*}$ state delocalized over the entire molecule. The $o-\mathrm{NH}_{2}$ substitution causes not only a red shift of the observed transitions but also the intensification, especially for the second absorption band that became more intense than the first. This band seems to be more affected by the substitution. In the case of the $o-\mathrm{OH}$ derivative (Table 3), this band is red shifted to the extent that it became obscured under the broad long wavelength band.

Inspection of Fig. 7 and Table 3 clearly indicates that the general features of the spectra of the para substituted derivatives are essentially the same as those of the corresponding ortho derivatives. In general, the electron donating substitution causes a red shift and the intensification of the observed transitions. The second absorption band originally appearing at $320 \mathrm{~nm}$ is most affected by the substitution. It is a red shift to $340 \mathrm{~nm}$ and may become obscured by the broad long wavelength band. It is interesting to note that the hydroxyl group substitution either in the ortho or para positions causes the coupling of the $\mathrm{C}-\mathrm{N}$ stretching mode with the asymmetric aromatic $\mathrm{C}=\mathrm{C}$ stretching and $\mathrm{OH}$ bending modes. These two coupling modes appear at $1660 \mathrm{~cm}^{-1}$ and $1608 \mathrm{~cm}^{-1}$. The two OH groups, on the other hand, do not couple with each other and appear at $3800 \mathrm{~cm}^{-1}$ and $3210 \mathrm{~cm}^{-1}$ (Table 4).

\section{CONCLUSIONS}

The present experimental and DFT/TDDFT investigations of the electronic structure and spectra of SA and some of its derivatives reveal that SA enjoys linear conjugation which is responsible for the observed spectrum. No specific part of the molecule reflects itself in the observed spectrum due to the extended $\pi$ system. The interaction between the oxygen and hydrogen atomic orbitals is of a covalent character, and thus, a proton transfer toward the nitrogen atom in the ground state would be opposed by a high energy barrier. A set of 12 substituted SA derivatives has been investigated. The choice of these substituents aims to create a push-pull system on the SA basic structure, which would shade light onto its photo physics. The substitution by bulky groups in the ortho position of the $\mathrm{N}-\mathrm{Ph}$ moiety forces it out of the plane of the molecules, yet the $\pi$ conjugation and hyperconjugation across the $\mathrm{C}=\mathrm{N}$ bond minimized the effect of non-coplanarity on the observed spectrum. The observed transitions are sensitive to both solvent and substituent effects. The extent of the charge transfer character and its direction enabled the interpretation of the observed shifts in band positions and intensities. The analysis of the experimentally determined and theoretically computed FTIR spectra of SA enabled the identification of three "IR marker bands", namely, the $\mathrm{OH}$ stretching mode at $3175 \mathrm{~cm}^{-1}$, the $\mathrm{C}=\mathrm{N}$ stretching mode at $1660 \mathrm{~cm}^{-1}$, and the $\mathrm{C}=\mathrm{N}$ and ring breathing combination band at $850 \mathrm{~cm}^{-1}$. These bands are persistent in all substituted SAs studied in the present work and are sensitive to the type and position of the substitution. 
$\mathrm{Tab}$ e 4

Experimentally observed and theoretically computed vibrational spectral characteristics and assignments of IR marker bands of SA and some of its derivatives

\begin{tabular}{|c|c|c|c|c|}
\hline Compound & $v_{\text {exp }}, \mathrm{cm}^{-1}$ & $v_{\text {calc }}, \mathrm{cm}^{-1}$ & $\begin{array}{l}\text { Relative } \\
\text { Intensity }\end{array}$ & Assignment \\
\hline SA & $\begin{array}{c}3600-2800(\mathrm{w}) \\
1613(\mathrm{~s}) \\
751(\mathrm{vs})\end{array}$ & $\begin{array}{c}3175 \\
1663,1660 \\
1606 \\
859 \\
\end{array}$ & $\begin{array}{c}334 \\
43,160 \\
140 \\
8.9 \\
\end{array}$ & $\begin{array}{c}\text { OH str. } \\
\mathrm{C}=\mathrm{N} \text { str., } \mathrm{C}=\mathrm{N} \text { str }+\mathrm{OH} \text { bending } \\
\mathrm{C}=\mathrm{N} \text { str. }+ \text { ring breathing vibration }\end{array}$ \\
\hline$p-\mathrm{NO}_{2}$ & $\begin{array}{c}3600-2800(\mathrm{w}) \\
1599(\mathrm{~s}) \\
1561(\mathrm{~s}) \\
759(\mathrm{vs}) \\
\end{array}$ & $\begin{array}{r}3276 \\
1664 \\
1660 \\
790 \\
\end{array}$ & $\begin{array}{r}514 \\
212 \\
383 \\
5 \\
\end{array}$ & $\begin{array}{c}\text { OH str. } \\
\mathrm{C}=\mathrm{N} \\
\mathrm{C}=\text { Nstr. }+\mathrm{OH} \text { bending } \\
\mathrm{C}=\text { Nstr.+ring breathing }\end{array}$ \\
\hline$o-\mathrm{Cl}$ & $\begin{array}{c}3600-2800(\mathrm{w}) \\
1608(\mathrm{~s})\end{array}$ & $\begin{array}{r}3252 \\
1670 \\
918 \\
\end{array}$ & $\begin{array}{r}575 \\
362 \\
36 \\
\end{array}$ & $\begin{array}{c}\mathrm{OH} \text { str. } \\
\mathrm{C}=\mathrm{N} \text { str. } \\
\mathrm{C}=\text { Nstr. }+ \text { ring breathing }\end{array}$ \\
\hline$p-\mathrm{OCH}_{3}$ & $\begin{array}{c}3600-2800(\mathrm{w}) \\
1608(\mathrm{~s}) \\
833(\mathrm{vs})\end{array}$ & $\begin{array}{r}3203 \\
1664 \\
919 \\
\end{array}$ & $\begin{array}{r}507 \\
316 \\
15 \\
\end{array}$ & $\begin{array}{c}\mathrm{OH} \text { str. } \\
\mathrm{C}=\text { Nstr. Coupled with ring modes } \\
\mathrm{C}=\text { Nstr. }+ \text { ring breathing }\end{array}$ \\
\hline$o-\mathrm{OH}$ & $\begin{array}{c}3600-2800(\mathrm{w}) \\
1613(\mathrm{~s}) \\
1590(\mathrm{~s}) \\
736(\mathrm{vs}) \\
\end{array}$ & $\begin{array}{r}3120 \\
3800 \\
1660 \\
1608 \\
854 \\
\end{array}$ & $\begin{array}{r}452 \\
48 \\
156 \\
143 \\
25 \\
\end{array}$ & $\begin{array}{c}\text { OH str. } \\
\text { OH str. (salisaylidene) } \\
\mathrm{C}=\mathrm{N} \text { str. Coupled with ring modes } \\
\mathrm{C}=\mathrm{N} \text { str. }+\mathrm{OH} \text { bending } \\
\mathrm{C}=\mathrm{N} \text { Str.+ring breathing }\end{array}$ \\
\hline$p-\mathrm{Br}$ & $\begin{array}{c}3600-3200(\mathrm{~s}) \\
1606(\mathrm{~s}) \\
828(\mathrm{vs}) \\
\end{array}$ & $\begin{array}{r}3197 \\
1659 \\
792 \\
\end{array}$ & $\begin{array}{r}280 \\
287 \\
7 \\
\end{array}$ & $\begin{array}{l}\text { OHstr. Coupled with arom.CH } \\
\qquad \mathrm{C}=\text { Nstr. } \\
\mathrm{C}=\text { Nstr.+ring breathing }\end{array}$ \\
\hline$o-\mathrm{Br}$ & $\begin{array}{c}3600-3200(\mathrm{w}) \\
1611(\mathrm{~s}) \\
1185(\mathrm{~s}) \\
752(\mathrm{vs}) \\
\end{array}$ & $\begin{array}{r}3156 \\
3136 \\
1656 \\
1000 \\
865 \\
\end{array}$ & $\begin{array}{r}370 \\
72 \\
242 \\
172 \\
14 \\
\end{array}$ & $\begin{array}{c}\text { OHstr. } \\
\text { OHstr.Coupled with. } \mathrm{CH}(\mathrm{C}=\mathrm{N}) \\
\mathrm{C}=\text { Nstr. } \\
\mathrm{C}=\text { Nstr. Oupled with } \mathrm{OH} \text { bending } \\
\mathrm{C}=\text { Nstr.+ring breathing }\end{array}$ \\
\hline$p-\mathrm{Cl}$ & $\begin{array}{l}3059(\mathrm{~s}) \\
2938(\mathrm{~s}) \\
1615(\mathrm{w}) \\
744(\mathrm{vs}) \\
\end{array}$ & $\begin{array}{r}3200 \\
3190 \\
1665 \\
780 \\
\end{array}$ & $\begin{array}{r}170 \\
148 \\
716 \\
19 \\
\end{array}$ & $\begin{array}{c}\text { OHstr. +arom.CH } \\
\text { OHstr.+arom.CH } \\
\mathrm{C}=\mathrm{N} \text { str. } \\
\mathrm{C}=\text { Nstr.+ring breathing }\end{array}$ \\
\hline$o-\mathrm{NO}_{2}$ & $\begin{array}{c}3375(w) \\
3344(w) \\
1623(s) \\
738 \\
\end{array}$ & $\begin{array}{r}3316 \\
1680 \\
845 \\
\end{array}$ & $\begin{array}{l}600 \\
541 \\
32.4\end{array}$ & $\begin{array}{c}\text { OHstr. } \\
\mathrm{C}=\text { Nstr. } \\
\mathrm{C}=\text { Nstr. }+ \text { ring breathing }\end{array}$ \\
\hline$p-\mathrm{OH}$ & $\begin{array}{l}3389(\mathrm{~s}) \\
3300(\mathrm{w}) \\
1612(\mathrm{w}) \\
835(\mathrm{vs})\end{array}$ & $\begin{array}{r}3835 \\
3206 \\
1665 \\
871\end{array}$ & $\begin{array}{l}107 \\
494 \\
300 \\
8.7\end{array}$ & $\begin{array}{c}\text { OH str. } \\
\text { OH str. (salisaylidene) } \\
\mathrm{C}=\mathrm{N} \text { str. Coupled with ring modes } \\
\mathrm{C}=\mathrm{N} \text { Str.+ring breathing }\end{array}$ \\
\hline
\end{tabular}




\section{REFERENCES}

1. Dudek G.O., Dudek E.P. // J. Amer. Chem. Soc. - 1966. - 88. - P. 2407.

2. Rosenfeld T., Ottolenghi M., Meyer A.Y. // Mol. Photochem. - 1973. - 5. - P. 39.

3. Lewis J.W., Sandorfy C. // Canad. J. Chem. - 1982. - 60. - P. 1727.

4. Becker R.S., Lenoble C., Zein A. // J. Phys. Chem. - 1987. - 91. - P. 3509.

5. Elsässer T., Bakker H.J. Ultrafast hydrogen bonding dynamics, proton transfer processes in the condensed phase, Kluwer Academic Publ., 2002.

6. Hadjoudis E., Mavridis I.M. // Chem. Soc. Rev. - 2004. - 33. - P. 579.

7. Irie M. // Chem. Rev. - 2000.-100. - P. 1685.

8. Vargas V., Amigo L. // J. Chem. Soc., Perkin Transactions. - 2001. - 2. - P. 1124.

9. Dziembowska T., Jagodzińska E., Rozwadowski Z., Kotfica M. // J. Mol. Struct. - 2001. - 598. - P. 229.

10. Ogawa K., Harada J., Fujiwara T., Yoshida S. // J. Phys. Chem. A. - 2001. - 105. - P. 3425.

11. Mandal A., Fitzmaurice D., Waghorne E., Koll A., Filarowski A., Guha D., Mukherjee S. // J. Photochem., Photobiol. A: Chemistry. - 2002. - 153. - P. 67.

12. Rospenk M., Król-Starzomska I., Filarowski A., Koll A. // Chem. Phys. - 2003. - 287. - P. 113.

13. Ohshima A., Momotake A., Arai T. // J. Photochem., Photobiol. A: Chemistry. - 2004. - 162. - P. 473.

14. Fabian W.M., Antonov L., Nedeltcheva D., Kamounah F.S., Taylor P.J. // J. Phys. Chem. A. - 2004. - 108. - P. 7603.

15. Barbara P., Rentzepis P., Brus L. // J. Amer. Chem. Soc. - 1980. - 102. - P. 2786.

16. Kownacki K., Mordzinski A., Wilbrandt R., Grabowska A. // Chem. Phys. Lett. - 1994. - 227. - P. 270.

17. Grabowska A., Kownacki K. // J. Luminescence. - 1994. - 60. - P. 886.

18. Zgierski M.Z., Grabowska A. // J. Chem. Phys. - 2000. - 112. - P. 6329.

19. Knyazhansky M., Metelitsa A., Kletskii M., Millov A., Besugliy S. // J. Mol. Struct. - 2000. - 526. - P. 65.

20. Joshi H., Kamounah F.S., Gooijer C., van der Zwan G., Antonov L. // J. Photochem., Photobiol. A: Chemistry. - 2002. - 152. - P. 183.

21. Otsubo N., Okabe C., Mori H., Sakota K., Amimoto K., Kawato T., Sekiya H. // J. Photochem., Photobiol. A: Chemistry. - 2002. - 154. - P. 33.

22. Mitra S., Tamai N. // Phys. Chem. Chem. Phys. - 2003. - 5. - P. 4647.

23. ZiółeM., Kubicki J., Maciejewski A., Naskręcki R., Grabowska A. // Phys. Chem. Chem. Phys. - 2004. - 6. - P. 4682.

24. Okabe C., Nakabayashi T., Inokuchi Y., Nishi N., Sekiya H. // J. Chem. Phys. - 2004. - 121. - P. 9436.

25. Mitra S., Tamai N. // Chem. Phys. Lett. - 1998. - 282. - P. 391.

26. Mitra S., Tamai N. // Chem. Phys. - 1999. - 246. - P. 463.

27. Vargas V. // J. Phys. Chem. A. - 2004. - 108. - P. 281.

28. Rodríguez-Córdoba Zugazagoitia W.J.S., Collado-Fregoso E., Peon J. // J. Phys. Chem. A. - 2007. - 111. - P. 6241.

29. Ziółek M., Kubicki J., Maciejewski A., Naskřcki R., Grabowska A. // J. Chem. Phys. - 2006. - 124. - P. 124518.

30. Frisch G.W.T. M.J., Schlegel H.B., Scuseria G.E., Robb M.A., Cheeseman J.R., Scalmani G., Barone V., Mennucci B., Petersson G.A., Nakatsuji H., Caricato M., Li X., Hratchian H.P., Izmaylov A.F., Bloino J., Zheng G., Sonnenberg J.L., Hada M., Ehara M., Toyota K., Fukuda R., Hasegawa J., Ishida M., Nakajima T., Honda Y., Kitao O., Nakai H., Vreven T., Montgomery J.A. Jr., Peralta J.E., Ogliaro F., Bearpark M., Heyd J.J., Brothers E., Kudin K.N., Staroverov V.N., Kobayashi R., Normand J., Raghavachari K., Rendell A., Burant J.C., Iyengar S.S., Tomasi J., Cossi M., Rega N., Millam J.M., Klene M., Knox J.E., Cross J.B., Bakken V., Adamo C., Jaramillo J., Gomperts R., Stratmann R.E., Yazyev O., Austin A.J., Cammi R., Pomelli C., Ochterski J.W., Martin R.L., Morokuma K., Zakrzewski V.G., Voth G.A., Salvador P., Dannenberg J.J., Dapprich S., Daniels A.D., Farkas O., Foresman J.B., Ortiz J.V., Cioslowski J., Fox D.J. Gaussian, Inc, Wallingford CT, 2009.

31. Schaefer T., Wildman T.A., Salman S.R. // J. Amer. Chem. Soc. - 1980. - 102. - P. 107.

32. Schaefer T., Salman S.R., Wildman T.A., Clark P.D. // Canad. J. Chem. - 1982. - 60. - P. 342.

33. Becke A.D. // J. Chem. Phys. - 1993. - 98. - P. 5648.

34. Bauernschmitt R., Ahlrichs R. // Chem. Phys. Lett. - 1996. - 256. - P. 454.

35. Ulic S.E., Védova C.O.D., Hermann A., Mack H.-G., Oberhammer H. // J. Phys. Chem. A. - 2008. - 112. - P. 6211.

36. Reed A.E., Weinhold F. // J. Chem. Phys. - 1983. - 78. - P. 4066.

37. Chen X., Yan F., Wu M., Tian H.-B., Li S.X., Shan X., Wang K., Li Z., Xu K. // Chem. Phys. Lett. - 2009. -472. - P. 19.

38. Frisch H.P.H. A.E., Dennington II R.D. et al. Gaussian, Inc., 235 Wallingford, CT, 2009. 